\title{
Biochar A Source of C Sink and Soil Health-A Review
}

\author{
Peeyush Sharma $^{1 *}$, Vikas Abrol$^{2}$, Neetu Sharma ${ }^{3}$ and Shrdha Anand ${ }^{4}$ \\ ${ }^{1}$ Division of Soil Science and Agricultural Chemistry, SKUAST-J, Chatha-180009, India \\ ${ }^{2}$ ACRA, Dhainsar, SKUAST-J, Chatha-180009, India \\ ${ }^{3}$ Division of Agronomy, SKUAST-J, Chatha-180009, India \\ ${ }^{4}$ GGM Science College, Jammu-180001, India
}

A B S T R A C T

\begin{tabular}{|l|}
\hline K e y w o r d s \\
$\begin{array}{l}\text { Biochar, Soil biological } \\
\text { properties, Carbon } \\
\text { sequestration, Crop } \\
\text { productivity }\end{array}$ \\
\hline Article Info \\
\hline $\begin{array}{l}\text { Accepted: } \\
\text { 28 March } 2018 \\
\text { Available Online: } \\
\text { 10 April 2018 }\end{array}$ \\
\hline
\end{tabular}

\section{Introduction}

Biochar refer to the carbon-rich materials (charcoal) obtained from the thermo-chemical conversion of biomass in an oxygen- limited environment (pyrolysis). Biochar was first found in the Central Amazon basin. Applying biochar to agricultural soils is considered to improve carbon sequestration and decreased greenhouse gas emissions from agriculture. Recently, biochar has gotten attention of researchers because of its capacity to improve water-holding capacity and nutrient-holding ability of soil because of its porous structure, high specific surface area, and CEC. Use of biochar can increase soil nutrient availability in the long term (Lehmann et al., 2003;
Rondon et al., 2007; Steiner et al., 2008). The use of biochar can enhance soil $\mathrm{pH}$ and soil CEC (Liang et al., 2006) and increase in soil water retention capacity and decrease in soil strength (Chan et al., 2007). Adoption of biochar management does not require new resources but makes use of locally available and renewable materials in a sustainable way. Biomass can include forestry and agricultural waste products, municipal green waste, biosolids, animal manures, some industrial wastes such as peppermill wastes. Soil organic matter is the key to soil health. In wet tropical condition, organic matter is easily subjected to decomposition and mineralization. Mineralization produces $\mathrm{CO}_{2}$ in just a few seasons and causes nutrient content to be low. 
Biochar significantly improve soil tilth, productivity, and nutrient retention and availability to plants via both direct slownutrient release fertilizing properties and indirect effects on improved water holding capacity, nutrient holding ability, and soil aggregate stability, when used as a soil conditioner along with organic and inorganic fertilizers. The world population is currently increasing at a fast rate and is expected to reach 9 billion by 2050. To meet a growing demand for food from a growing population, we need to increase agricultural productivity upto $70 \%$, and food production in the developing world will need to double by 2050 (FAO). The main challenge facing the future of agricultural production is to produce almost $50 \%$ more food up to 2030, and double production by 2050 .

\section{Crop residues management: a burning issue}

The management and utilization of crop residues is essential for the improvement of soil quality and crop productivity. Viable option is to retain residue in the field; burning should be avoided. India, with a long history of agricultural activities, produces vast amounts of unusable crop residues at about 500 million tons/year (2010-2011). Studies sponsored by the Ministry of New and Renewable Energy (MNRE), Govt. of India have estimated surplus biomass availability at about 120-150 million tons/annum (MNRE, 2009). Of this, about 93 million tons of crop residues are burned in each year (IARI 2012). Direct incorporation of crop residues into agricultural soil to conserve soil moisture and nutrients can cause considerable crop management problems. However, long-term field research has confirmed that adding crop residues to agricultural soils leads to large increases in soil $\mathrm{C}$ stocks in the short term but minimal increases in the long term due to na1tural decay. For more effective management and disposal of the crop residues, conversion of organic waste to produce biochar is one viable option that can enhance natural rates of carbon sequestration in the soil, reduce farm waste and improve the soil quality (Srinivasarao et al., 2012).

\section{Biochar for waste management}

"Biochar" is a relatively new term, yet it is not a new substance. It actually comes from the study of very old soils in the Amazon Basin. The so-called "Terra preta de Indio", or "black soil of the Indians" was formed by indigenous peoples centuries to thousands of years ago when they accumulated charcoal and other fire residues, and also nutrient-rich waste such as animal and fish bones, in waste piles near dwellings. Over time these wastes resulted in black colored human-modified soils which are up to two meters deep, while the surrounding soils are reddish to yellowish.

Biochar is a charcoal based, soil amendment that can be designed to help reclaim and improve marginal soils by increasing soil water holding capacity and enhancing fertility, while also generating high-value renewable energy co-products during its production. Biochar is not a pure carbon, but rather mix of carbon $(\mathrm{C})$, hydrogen $(\mathrm{H})$, oxygen $(\mathrm{O})$, nitrogen $(\mathrm{N})$, sulphur $(\mathrm{S})$ and ash in different proportions (Masek, 2009). The central quality of biochar and char that makes it attractive as a soil amendment is its highly porous structure, potentially responsible for improved water retention and increased soil surface area. Biochar is created by heating organic material under conditions of limited or no oxygen. Production of biochar generally releases more energy than it consumes, depending on the moisture content of the feedstock. Heat, oil, and gas that are released can be recovered for other uses, including the production of electricity. Biochar and its byproducts can be produced from a wide variety of feed stocks such as organic farm waste, waste treatment plant slurry, and woods 
with high cellulose/lignin content. After pyrolysis, the solid byproduct is a porous network of carbonates and/or aromatic carbon. Different feedstocks used lead to different properties (Table 1).

\section{Biochar as a source of $\mathrm{C}$ sink}

Fossil fuels are carbon positive; they add more carbon dioxide $\left(\mathrm{CO}_{2}\right)$ and other greenhouse gasses to the air and thus exacerbate global warming. Ordinary biomass fuels are carbon neutral; the carbon captured in the biomass by photosynthesis would have eventually returned to the atmosphere through natural processes like decomposition. Sustainable biochar systems can be carbon negative by transforming the carbon in biomass into stable carbon structures in biochar which can remain sequestered in soils for hundreds and even thousands of years.

\section{Restoring the carbon balance in the atmosphere}

It removes net carbon from the atmosphere. When a green plant grows, it takes $\mathrm{CO}_{2}$ out of the air to build biomass. All of the carbon in the plant came from $\mathrm{CO}_{2}$ taken out of the air, and returns to the air when the plant dies and decomposes. When the biomass is pyrolyzed-heated in the absence of oxygen-over $40 \%$ of the total carbon from the waste biomass is retained in biochar and sequestered in the soil for thousands of years, effectively removing that carbon from the atmosphere. The carbon in 1 ton of biochar is equivalent to about 3 tons of $\mathrm{CO}_{2}$ removed from the atmosphere.

\section{Biochar as a soil amendment}

Biochar application to soil leads to several interactions mainly with soil matrix, soil microbes, and plant roots (Lehmann and Joseph, 2007). The types and rates of interactions depend on different factors like composition of biomass as well as biochar, methods of biochar preparation, physical aspect of biochar and soil environmental condition mainly soil temperature and moisture.

\section{Soil chemical properties}

Biochar is generally alkaline in $\mathrm{pH}$ and may increase soil pH (Chan and XU, 2009), cation exchange capacity, base saturation, exchangeable bases and organic carbon content as well as decreases in $\mathrm{Al}$ saturation in acid soils (Glaser et al., 2002). Biochar addition can increase the $\mathrm{pH}$ of amended soils by 0.4 to $1.2 \mathrm{pH}$ units with greater increase observed in sandy and loamy soils than in clayey soils (Tyron et al., 1948). Widowati et al., (2012) observed that incorporation of biochar increased organic carbon and decreased nitrogenous fertilizer requirement. Similar results were also obtained with different types of feedstocks and soil (Rondon et al., 2007, Novak et al., 2009, Laird et al., 2010). The increase in soil carbon through biochar application is attributed to the stability of biochar in the soil which persists despite microbial action. Lehmann et al., (2003) and Steiner et al., (2008) reported that the use of biochar can improve the efficiency of nitrogen fertilizer, as biochar can reduce the loss of nitrogen and potassium that occurs through leaching (Widowati et al., 2011). In addition to this, Glaser et al., (2002) concluded that the charcoal may be more than just a soil conditioner, but may act as a fertilizer itself, as seen also in the results of Chan et al., (2008). Sukartono et al., (2011) reported that application of biochar improved soil fertility status, as soil organic carbon, cation exchange capacity, available phosphorus, exchangeable potassium, calcium and magnesium of the sandy soils in Lombok, Indonesia the increasing aromatic carbon is likely to affect soil properties. 
Table.1 Properties of biochar used in different experiment

\begin{tabular}{|c|c|c|c|c|c|c|c|c|c|c|}
\hline Materials used for & \multirow[t]{2}{*}{ pH } & $\begin{array}{c}\text { Total } \\
\text { C }\end{array}$ & $\begin{array}{c}\text { Total } \\
\mathbf{N}\end{array}$ & \multirow[t]{2}{*}{$\mathrm{C}: \mathrm{N}$} & \multirow[t]{2}{*}{$\mathrm{Ca}$} & \multirow[t]{2}{*}{ Mg } & \multirow{2}{*}{$\begin{array}{c}P \\
(\mathrm{cmol} / \mathrm{k} \mathrm{g})\end{array}$} & \multirow[t]{2}{*}{$\mathbf{K}$} & \multirow[t]{2}{*}{ CEC } & \multirow[t]{2}{*}{ Reference } \\
\hline Producing biochar & & \multicolumn{2}{|c|}{$(\%)$} & & & & & & & \\
\hline $\begin{array}{l}\text { Paper mill waste } 1- \\
\text { (waste wood chip) }\end{array}$ & 9.4 & 50.0 & 0.48 & 104 & 6.2 & 1.20 & - & 0.22 & 9.00 & Zwieten et al., (2010) \\
\hline $\begin{array}{l}\text { Paper mill waste } 2- \\
\text { (waste wood chip) }\end{array}$ & 8.2 & 52.0 & 0.31 & 168 & 11.0 & 2.60 & - & 1.00 & 18.00 & Zwieten et al., (2010) \\
\hline $\begin{array}{l}\text { Green waste (grass clippings, } \\
\text { cotton trash and plant prunings) }\end{array}$ & 9.4 & 36.0 & 0.18 & 200 & 0.4 & 0.56 & - & $\begin{array}{c}21.0 \\
0\end{array}$ & 24.00 & Chan et al., (2007) \\
\hline Eucalyptus biochar & - & 82.4 & 0.57 & 145 & - & - & 1.87 & - & 4.69 & Novak et al., (2009) \\
\hline Cooking biochar & - & 72.9 & 0.76 & 96 & - & - & 0.42 & - & 11.19 & Novak et al., (2009) \\
\hline Poultry litter $\left(450^{\circ} \mathrm{C}\right)$ & 9.9 & 38.0 & 2.00 & 19 & - & - & 37.42 & - & - & Chan et al., (2008) \\
\hline Poultry litter $\left(550^{\circ} \mathrm{C}\right)$ & 13 & 33.0 & 0.85 & 39 & - & - & 5.81 & - & - & Chan et al., (2008) \\
\hline Wood biochar & 9.2 & 72.9 & 0.76 & 120 & 0.83 & 0.20 & 0.10 & 1.19 & 11.90 & Major (2013) \\
\hline Hardwood sawdust & - & 66.5 & 0.3 & 221 & - & - & - & - & - & Singh et al., (2010) \\
\hline Mixed wood & 8.13 & 88.9 & & & 50.9 & & & 14 & & Abrol et al., (2016) \\
\hline
\end{tabular}


Table.2 Effect of biochar addition on soil properties

\begin{tabular}{|c|c|c|c|c|}
\hline Property & Effect & $\begin{array}{l}\text { Biochar } \\
\text { property }\end{array}$ & Mechanism & Reference \\
\hline $\begin{array}{l}\text { Soil } \\
\text { Organic } \\
\text { matter }\end{array}$ & Increased & High $\mathrm{C}$ content & $\begin{array}{l}\text { Increased carbon } \\
\text { concentration }\end{array}$ & Zhang et al., (2012) \\
\hline $\begin{array}{l}\text { Water-holding } \\
\text { capacity }\end{array}$ & Increased & $\begin{array}{l}\text { Porous } \\
\text { structure }\end{array}$ & $\begin{array}{l}\text { Increased macro } \\
\text { porosity and } \\
\text { hydrophilicity }\end{array}$ & $\begin{array}{l}\text { Herath et al.,(2012), } \\
\text { Atkinson } \text { et al.,(2010) }\end{array}$ \\
\hline Porosity & Increased & $\begin{array}{l}\text { Porous } \\
\text { structure }\end{array}$ & $\begin{array}{c}\text { Dilution effect and } \\
\text { formation of macro } \\
\text { aggregates }\end{array}$ & Herath et al., (2013) \\
\hline $\begin{array}{c}\text { Plant } \\
\text { Crop yield }\end{array}$ & Increased & $\begin{array}{l}\text { Soil organic } \\
\text { matter, } \mathrm{pH} \text {, } \\
\text { bulk density, } \\
\mathrm{CEC} \text {, high } \\
\text { porosity }\end{array}$ & $\begin{array}{l}\text { Due to the positive } \\
\text { effect of soil quality; } \\
\text { chemical, physical, } \\
\text { microbial and } \\
\text { nutrient availability }\end{array}$ & Zhang et al., (2012) \\
\hline $\begin{array}{l}\text { Environment } \\
\mathrm{CH}_{4} \text { emissions }\end{array}$ & Decrease & $\begin{array}{c}\text { Porous } \\
\text { structure, } \mathrm{pH}\end{array}$ & $\begin{array}{l}\text { Abundance of } \\
\text { methanotrophic } \\
\text { proteobacterial, } 37 \\
\text { methenogenic } \\
\text { bacteria reduced at } \\
\text { too high or too } \\
\text { low pH }\end{array}$ & Feng et al.,(2012) \\
\hline $\mathrm{N}_{2} \mathrm{O}$ emissions & Decreased & $\begin{array}{l}\text { Recalcitrant, } \\
\text { porous } \\
\text { structure }\end{array}$ & $\begin{array}{c}\text { Enhanced aeration } \\
\text { and stable carbon, } \\
\text { increased } \\
\text { microbial activity } \\
\text { and immobilization } \\
\text { of } \mathrm{N}\end{array}$ & Zhang et al., (2012) \\
\hline $\begin{array}{c}\text { Carbon } \\
\text { sequestration }\end{array}$ & Increased & $\begin{array}{l}\text { Recalcitrant or } \\
\text { stable C; } \\
\text { Recalcitrant or } \\
\text { stable C; }\end{array}$ & $\begin{array}{l}\text { Long-term storage } \\
\text { of stable carbon in } \\
\text { soil }\end{array}$ & $\begin{array}{c}\text { Kameyama et } \\
\text { al.,(2010),Matovic et } \\
\text { al.,(2011) }\end{array}$ \\
\hline $\begin{array}{l}\text { Nutrient } \\
\text { leaching }\end{array}$ & Decreased & $\begin{array}{c}\text { Porous } \\
\text { structure, } \\
\text { surface area } \\
\text { and negative } \\
\text { surface charge }\end{array}$ & $\begin{array}{l}\text { Enhanced CEC } \\
\text { facilitates retention } \\
\text { of nutrients }\end{array}$ & $\begin{array}{l}\text { Biederma and Harpole } \\
\text { (2012) }\end{array}$ \\
\hline
\end{tabular}


Table.3 Effect of biochar application on crop yield

\begin{tabular}{|c|c|c|c|c|c|}
\hline Crops & Soil type & $\begin{array}{l}\text { Biochar } \\
\text { treatment } \\
(\mathbf{t} \cdot \mathbf{h a}-1)\end{array}$ & $\begin{array}{c}\text { Fertilizer } \\
\text { treatment } \\
(\mathrm{kg} \cdot \mathrm{ha}-1)\end{array}$ & $\begin{array}{c}\text { Yield } \\
\text { increase over } \\
\text { control a (\%) }\end{array}$ & Reference \\
\hline Wheat & Ferrosol & 0 and 10 & $\begin{array}{c}1.25 \mathrm{~g} \\
\text { Nutricote } \AA \text { per } \\
250 \mathrm{~g} \text { soil b }\end{array}$ & +250 & $\begin{array}{c}\text { Van Zwieten et al., } \\
\text { (2010) }\end{array}$ \\
\hline Radish & Alfisol & $\begin{array}{c}0,10,25 \text { and } \\
50\end{array}$ & $\mathrm{~N}(100)$ & +320 & Chan et al., (2008) \\
\hline Radish & Alfisol & $\begin{array}{c}0,10,50 \text { and } \\
100\end{array}$ & $\mathrm{~N}(100)$ & +95 to +266 & Chan et al., (2007) \\
\hline Maize & $\begin{array}{c}\text { Fine sand } \\
\text { loam and } \\
\text { sand }\end{array}$ & $\begin{array}{c}0,2.5,5.0 \text { and } \\
10\end{array}$ & Nil & No effect & Feng et al., (2012) \\
\hline Wheat & Silt loam & 0 and 9 & Nil & No effect & $\begin{array}{l}\text { Karhu et al., } \\
\text { (2011) }\end{array}$ \\
\hline Maize & Oxisol & 0,8 and 20 & $\begin{array}{c}\text { Lime (dolomite) } \\
(2.2) ; \mathrm{N}(156- \\
170 ; \mathrm{P}(30- \\
43) ; \mathrm{K}(84- \\
138)\end{array}$ & $\begin{array}{c}+28(2004)+ \\
30(2005)+ \\
140(2006)\end{array}$ & Major (2010) \\
\hline Maize & Ultisol & 0 and 2.4 & $\begin{array}{c}\mathrm{N}(150) ; \mathrm{P}_{2} \mathrm{O}_{5} \\
(100) ; \mathrm{K}_{2} \mathrm{O} \\
(150)\end{array}$ & +146 & Peng et al., (2011) \\
\hline Beans & Oxisol & $\begin{array}{c}0,30,60 \text { and } \\
90^{c}\end{array}$ & $\begin{array}{l}\text { Lime }(300) ; \mathrm{N} \\
(20) ; \mathrm{P}(20)\end{array}$ & +39 & $\begin{array}{l}\text { Rondon et al., } \\
\text { (2007) }\end{array}$ \\
\hline
\end{tabular}

Since biochar is highly porous and has a large specific surface area, its impact on soil cation exchange capacity and other nutrients that have correlation with cation exchange capacity is very important. Biochar amendment significantly decreased extracted $\mathrm{Cd}$ in the soil by 17 to 47 per cent. Some types of biochar also appear to reduce the mobility of heavy metals such as $\mathrm{Cu}$ and $\mathrm{Zn}$

\section{Soil physical properties}

Little research has been published on the effects of biochar on physical properties. Studies showed biochar effects on parameters such as bulk density, porosity, water holding capacity and aggregate stability (Table 2). Tyron (1948) reported that in a sandy soil, there was a monotonic increase in the per cent of available moisture as a function of charcoal volumetric proportion with an increase of about 6 per cent available moisture per cent under any amendment amount, while the available moisture per cent in the clay soil decreased by nearly 7 per cent under a 15 volume per cent load of charcoal has been argued to enhance soil physical properties, including soil water retention and aggregation both of which may improve water availability to crops as well as decrease erosion (Glaser $e t$ 
al.,2002). Glaser et al., (2002) observed that charcoal rich anthrosols from the Amazon region whose surface area was 3 times greater than that of surrounding soils which have 18 per cent greater field capacity. Further charcoal has also been reported to form complexes with minerals as a result of interactions between oxidized carboxylic acid groups at the surface of the charcoal particles and mineral grains soil aggregate stability (Glaser et al., 2002). Chan et al., (2007) observed improvement in texture and behavior of a hard setting soil with significant reduction in tensile strength at higher rates of biochar application. Several studies showed enhanced soil water holding capacity (Asai et al., 2009, Karhu et al., 2011), improved soil water permeability (Asai et al., 2009), improved saturated hydraulic conductivity, reduced soil strength, modification in soil bulk density (Laird et al., 2010), modified aggregate stability (Busscher et al., 2010, Peng et al., 2011). Soil amendment with biochar can result in decreased bulk density and soil penetration resistance and increased water holding capacity (Abrol et al., 2016). Most research findings point to the improvement of bulk density with biochar application (Karhu et al., 2011). Biochar has high porosity which allows high water holding capacity. However it is hydrophobic as it is dry due to its high porosity and light bulk density. Addition of biochar to the soil improves soil physical property, water permeability and aggregate stability (Table 2). Peng et al., (2011) reported that compared with fertilizer application biochar amendment to a typical soil ultisol resulted in better crop growth.

\section{Soil biological properties}

The soil biota is vital for the functioning of soils providing many essential ecosystem services. The addition of biochar to the soil is likely to have different effects on the soil biota. In the long term experiments, application of biochar had no significant influence on basal application rates compared with the control. Graber et al., (2009) reported that with increasing rate of biochar application maximum number of culturable colonies of general bacteria, Bacillus spp. yeasts and Trichoderma spp. were found. However minimum number of culturable colonies of filamentous fungi Pseudomonas spp and Actinomycetes spp were found in the soil. The positive effects have been reported to enhanced biological nitrogen fixation (Rondon et al., 2007), improved colonization of mycorrhizal fungi, earthworms showed preference to biochar amended soils (Van Zwieten et al., 2010), increased methane uptake (Karhu et al., 2011), potential catalyst in reducing nitrous oxide to nitrogen (Van Zwieten et al., 2009)

\section{Crop productivity}

The response of different crops to various biochar application levels is summarized in table 3. Application of biochar can enhance soil productivity by improving the physical, chemical and biological soil conditions (Glaser et al., 2007, Lehmann et al., 2003, Chan et al., 2007). Improvement in soil structure increase in soil water retention and decrease in soil strength have been reported by Chan et al., (2007) conducted a study on Australian soil. Lehmann et al., (2003) compared soil fertility and leaching losses of nutrients between an Anthrosol and an adjacent unamend Ferralsol. The Anthrasol showed significantly higher $\mathrm{P}, \mathrm{Ca}, \mathrm{Mn}$ and $\mathrm{Zn}$ availability than the Ferralsol, and an increased biomass of both cowpea and rice by $38-45 \%$ without fertilization. The application of paper mill waste biochar, combined with inorganic fertilizer, showed higher soybean and radish biomass compared with sole application of inorganic fertilizer (Van Zwieten et al., 2010). Application of chicken 
manure and city waste biochar increased maize biomass (Widowati et al., 2012). This higher biomass production is attributed to biochar increasing the soil $\mathrm{pH}$ and CEC (Liang et al., 2006). Crop yields of soybeans were also reported to increase by a factor of 1.5 after an application of $0.5 \mathrm{Mg}$ charcoal/ha (Kishimoto and Sugiura, 1985).

Results showed that the application of biochar to soil has been shown to improve soil quality and crop yields which could be due to direct or indirect effect. Biochar is able to play a major role in expanding options for sustainable soil management by improving upon existing best management practices, not only to improve soil productivity but also to decrease the environmental impact on soil and water resources. Future long term field studies are necessary to evaluate the effect of biochar on soil properties and $\mathrm{C}$ sequestration for sustainable crop production.

\section{References}

Abrol, Vikas, Meni Ben-Hur, Frank G. A. Verheijen, Jacob J. Keizer, Martinho A. S. Martins, Haim Tenaw, Ludmilla Tchehansky, Ellen R Graber E. 2016. Biochar effects on soil water infiltration and erosion under seal formation conditions: rainfall simulation experiment. J. of Soils and Sediments, 16 (12): 27092719.

Asai, H., Samson, B.K., Stephan, H.M., Songyikhangsuthor, K., Homma, K., Kiyono, Y., Inoue, Y., Shiraiwa, T. and Horie, T., 2009. Biochar amendment techniques for upland rice reduction in Northern Laos 1. Soil physical properties, leaf SPAD and grain yield. Field Crop Res. 111: $81-84$

Atkinson, C., Fitzgerald, J. and Hipps, N.2010. Potential mechanisms for achieving agricultural benefits from biochar application to temperate soils: a review. Plant Soil, 2010, 337: 1-18.
Biederman, L. A. and Harpole, W. S. 2012. Biochar and its effects on plant productivity and nutrient cycling: a meta- analysis. $G C B$ Bioenergy, 2(5): 202-214.

Busscher, W.J., Novak, J.M., Evans, D.E., Watts, D.W., Niandou, M.A.S. and Ahmedna, M., 2010. Influence of pecan biochar on physical properties of a Norfolk loamy sand. Soil Science. 175: 10 - 14.

Chan, K. Y., Van Zwieten, L., Meszaros, I., Downie, A., Joseph, S. 2007. Agronomic values of green waste biochar as a soil amendment. Aus. J. Soil Res. 45 (8): 629634.

Chan, K. Y., Van Zwieten, L., Meszaros, I., Downie, A., Joseph, S. 2008. Using poultry litter biochar as soil amendments. Aus. J. Soil Res. 46 (5): 437-444.

Chan, K.Y. and Xu, Z., 2009. Biochar: nutrient properties and their enhancement. Chapter 5. In: Lehmann, J. and Joseph, S. (Eds.), Biochar for Environmental Management Science and Technology, Earthscan, London: $67-84$.

Chan, K.Y., Van Zwieten, L., Meszaros, I., Downie, A. and Joseph, S., 2007. Agronomic

Feng, Y., Xu, Y., Yu, Y., Xie, Z. and Lin, X.2012 Mechanisms of biochar decreasing methane emission from Chinese paddy soils. Soil Biol. Biochem. 46: 80-88.

Feng, Y., Xu, Y., Yu, Y., Xie, Z. and Lin, X.2012. Mechanisms of biochar decreasing methane emission from Chinese paddy soils. Soil Biol. Biochem. 46: 80-88

Glaser, B., Guggenberger, G., Zech, W.2002 Past anthropogenic influence on the present soil properties of anthropogenic dark earths (Terra Preta) in Amazonia (Brazil). Geoarcheology

Glaser, B., Lehmann, J. and Zech, W.2002 Ameliorating physical and chemical properties of highly weathered soils in the tropics with charcoal - a review. Biology and Fertility of Soils 35 (4): 219- 230.

Graber, E.R.2009. Biochar for 21st century challenges: Carbon sink, energy source and soil conditioner. Conference Proceedings, Dahlia Gredinger International Symposium, Haifa, May 2009 
Herath, H. M. S. K., Camps-Arbestain, M. and Hedley, M. 2013. Effect of biochar on soil physical properties in two contrasting soils: an Alfisol and an Andisol. Geoderma, 209210: 188-197.

Herath, H. M. S. K., Camps-Arbestain, M. and Hedley, M.2013. Effect of biochar on soil physical properties in two contrasting soils: an Alfisol and an Andisol. Geoderma, 209210, 188-197.

Huang, M., Yang, L., Qin, H., Jiang, L. and Zou, Y.2013. Quantifying the effect of biochar amendment on soil quality and crop productivity in Chinese rice paddies. Field Crops Res. 154: 172-177.

IARI, 2012. Crop residues management with conservation agriculture: Potential, constraints and policy needs. Indian Agricultural Research Institute, New Delhi, $32 \mathrm{p}$.

Jha, P., Biswas, A.K., Lakaria, B.L. and Subba Rao, A. 2010. Biochar in agriculture prospects and related implications. Current Science, 99(9): 1218-1225.

Jien, S.H. and Wang, C.-S. 2013. Effects of biochar on soil properties and erosion potential in a highly weathered soil. Catena, 110: 225-233.

Kameyama, K., Shinogi, Y., Miyamoto, T. and Agarie, K. 2010. Estimation of net carbon sequestration potential with farmland application of bagasse charcoal: life cycle inventory analysis through a pilot sugarcane bagasse carbonization plant. Soil Res., 48: 586-592.

Karhu, K., Mattila, T., Bergström, I. and Regina, K., 2011. Biochar addition to agricultural soil increased $\mathrm{CH} 4$ uptake and water holding capacity - Results from a shorttermpilot field study. Agricultural, Ecosystems and Environment, 140: 309 313.

Kishimoto, S. and Sugiura, G.1985 Charcoal as a soil conditioner. Int. Achieve. Future 5: 1223.

Laird, D.A., Fleming, P., Davis, D.D., Horton, R., Wang, B. and Karlen, D., 2010. Impact of biochar amendments on the quality of typical Midwestern agricultural soil. Geoderma, 158: 443 - 449.
Laird, D.A., Fleming, P., Davis, D.D., Horton, R., Wang, B. and Karlen, D., 2010. Impact of biochar amendments on the quality of typical Midwestern agricultural soil. Geoderma, 158: 443 - 449.

Lehmann, J. 2007, 'A handful of carbon', Nature 447: 143-144

Lehmann, J., D.C. Kern, B. Glaser and W. I. Woods. 2003. Biochar and carbon sequestration. In: Amazonian Dark Earths: Origin, Properties, Management. Kluwer Academic Publishers, Netherlands, pp. 523

Lehmann, J.: 2007, 'A handful of carbon', Nature 447: 143-144

Lehmann, J., Pereira da Silva Jr., J., Steiner, C., Nehls, T., Zec, W., Glaser, B.2003. Nutrient availability and leaching in an archaeological Anthrosol and a Ferralsol of the Central Amazon basin: fertilizer, manure and charcoal amendments. Plant and Soil 249: 343-357.

Liang, B., Lehmann, J., Solomon, D., Kinyargi, J., Grossman, J., O’Neill, B., Skemjstad,

Major, J. 2013. Practical aspects of biochar application to tree crops. IBI Technical Bulletin \#102, International Biochar Initiative. (Accessed online at http://www. biocharinternational.org/sites/default/files/T echnical\%20Bulletin\%20Biochar\%20Tree $\% 20$ Planting.pdf).

Masek, O. 2009. Biochar production technologies, http://www.geos.ed.ac.uk/sccs/biochar/ documents/BiocharLaunch-OMasek.pdf.

Matovic, D. 2011. Biochar as a viable carbon sequestration option: global and Canadian perspective. Energy, 36(4): 2011-2016.

Matovic, D., 2011 Biochar as a viable carbon sequestration option: global and Canadian perspective. Energy, 36(4): 11-2016.

MNRE, 2009. Ministry of New and Renewable Energy Resources, Govt. of India, New Delhi. www.mnre.gov.in/biomassrsources.

Novak, J.M., Busscher, W.J., Laird, D.L., Ahmedna, M., Watts, D.W. and Niandou, M.A.S., 2009. Impact of biochar amendment on fertility of a southeastern coastal plan soil. Soil Science, 174: 105 112

Peng, X., Ye, L.L., Wang, C.H., Zhou, H. and Sun, B., 2011. Temperature and duration dependent rice straw-derived biochar: 
Characteristics and its effects on soilproperties of an Ultisol in southern China. Soil and Tillage Res., 112:159166.

Rondon, M.A., Lehmann, J., Ramirez, J. and Hurtado, M., 2007. Biological nitrogen fixation by common beans (Phaseolus vulgaris L.) increases with biochar additions. Biology and Fertility of Soil, 43: $699-708$.

Singh, B. P., Hatton, B. J., Singh, B., Cowie, A. L. and Kathuria, A. 2010. Influence of biochars on nitrous oxide emission and nitrogen leaching from two contrasting soils. J. Environ. Qual., 39:1224-1235.

Srinivasarao, Ch., Vankateswarlu, B., Lal, R., Singh, A.K., Sumanta Kundu, Vittal, K.P.R., Balaguruvaiah, G., Vijaya Shankar Babu, M., Ravindra Chary, G., Prasadbabu, M.B.B. and Yellamanda Reddy, T. 2012. Soil carbon sequestration and agronomic productivity of an Alfisol for a groundnutbased system in a semiarid environment in southern India. Eur. J. of Agronomy, 43: 40-48.

Srinivasarao, Ch., Venkateswarlu, B., Lal, R., Singh, A.K. and Sumanta Kundu. 2013. Sustainable management of soils of dryland ecosystems for enhancing agronomic productivity and sequestering carbon. Advances in Agronomy, 1: 21.

Steiner, C., Glaser, B., Teixera, W.G., Lehmann, J., Blum, W.E.H. and Zech, W., 2008. Nitrogen retention and plant uptake on a highly weathered central Amazonian Ferralsol amended with compost and charcoal. Journal of Plant Nutrition and Soil Science, 171: 893 - 899.

Sukartono, Utomo WH, Kusuma Z, Nugroho WH. 2011. Soil fertility status, nutrient uptake, and maize (Zea mays L.) yield following biochar application on sandy soils of Lombok, Indonesia. J. Trop. Agric. 49: 4752

Thies, J., J., Luizao, F., Peterson, J. and Noves, E., 2006. Black carbon increases cation exchange capacity in soil. Soil Science Society of America Journal, 70: 1719 1730.

Tyron, E. H.1948 Effect of charcoal on certain physical, chemical and biological properties of forest soils. Ecol Monograph18: 81-115.

Van Zwieten, L., Kimber, S., Morris, S., Chan, K.Y., Downie, A., Rust, J., Joseph, S. and Cowie, A., 2010. Effects of biochar from slow pyrolysis of papermill waste on agronomic performance and soil fertility. Plant and Soil, 327: 235 - 246.

Van Zwieten, L., Sigh, B., Joseph, S., Kimber, S., Cowie, A. and Chan, K.Y., 2009. Biochar and emissions of non-CO2 greenhouse gases from soil. In: Lehmann, J. and Joseph, S. (Eds.), Biochar for Environmental Management - Science and Technology, Earthscan, London: 227 - 247.

Widowati, Asnah, Sutoyo. 2012. The effects of biochar and potassium fertilizer on the absorption and potassium leaching. Buana Sains 12: 83-90

Widowati, Utomo WH, Soehono LA, Guritno B. 2011. Effect of biochar on the release and loss of nitrogen from urea fertilization. J. Agric. Food Technol. 1: 127-132

Yaman, S.2004. Pyrolysis of biomass to produce fuels and chemical feed stocks. Energy Conversion and Management. 45 (5), 651671.

Zhang, A. 2012. Effects of biochar amendment on soil quality, crop yield and greenhouse gas emission in a Chinese rice paddy: a field study of 2 consecutive rice growing cycles. Field Crops Res., 127: 153-160.

\section{How to cite this article:}

Peeyush Sharma, Vikas Abrol, Neetu Sharma and Shrdha Anand. 2018. Biochar A Source of C Sink and Soil Health-A Review. Int.J.Curr.Microbiol.App.Sci. 7(04): 3622-3631. doi: https://doi.org/10.20546/ijcmas.2018.704.408 